\title{
Factors Associated with Fatigue in Chronic Kidney Disease Patients Undergoing Hemodialysis: A Systematic Review
}

\section{Faktor yang Berhubungan dengan Kelelahan pada Pasien Gagal Ginjal Kronik yang Menjalani Hemodialisis: Sistematika Review}

\author{
Firman Prastiwi ${ }^{1}$, Titin Andri $W^{2}$, Dina Dewi SLI \\ ${ }^{1}$ Postgraduate Programme in Medical-surgical Nursing Faculty of Medicine Universitas Brawijaya Malang \\ ${ }^{2,3}$ Department of Nursing Faculty of Medicine Universitas Brawijaya Malang
}

\begin{abstract}
Fatigue is the primary complaint most frequently reported by patients on hemodialysis. The importance of knowing the factors related to fatigue is a strategy that can be carried out by health workers in optimally applying interventions to reduce patient fatigue problems. This systematic review aimed to determine the factors associated with fatigue in patients undergoing hemodialysis. The systematic review method began by identifying research articles in the Pubmed, ProQuest, Ebsco, and ScienceDirect databases in 2011-2020. Review protocol was using PRISMA. Based on the results of the analysis, it was obtained 23 articles that discussed demographic factors, physiological factors, socioeconomic factors, situational factors, and psychological factors that could be associated with fatigue in hemodialysis patients. There is much to learn about fatigue in patients undergoing hemodialysis, including causative factors, assessment of severity, and effective management of fatigue so that it can be used as a benchmark for determining appropriate interventions.
\end{abstract}

Keywords: Chronic kidney disease, fatigue, hemodialysis

\begin{abstract}
ABSTRAK
Fatigue merupakan keluhan utama yang paling sering dilaporkan oleh pasien dengan hemodialisis. Pentingnya mengetahui faktor yang berhubungan dengan fatigue menjadi strategi yang dapat dilakukan oleh tenaga kesehatan dalam mengaplikasikan intervensi secara optimal untuk mengurangi masalah fatigue pasien. Sistematik review ini bertujuan untuk mengetahui faktor yang berhubungan dengan fatigue pada pasien yang menjalani hemodialisis. Metode sistematika review dimulai dengan mengidentifikasi artikel penelitian pada database Pubmed, ProQuest, Ebsco, dan ScienceDirect tahun 2011-2020. Protokol sistematik review menggunakan PRISMA. Hasil analisis didapatkan 23 artikel yang membahas faktor demografi, fisiologis, sosial ekonomi, situasional dan psikologis yang berhubungan dengan dengan fatigue pada pasien hemodialisis. Banyak hal yang harus dipelajari mengenai fatigue pada pasien yang menjalani hemodialisis, termasuk faktor penyebab, penilaian keparahan, dan manajemen fatigue yang efektif sehingga dapat menjadi tolak ukur untuk menentukan intervensi yang tepat.
\end{abstract}

Kata Kunci: Gagal ginjal kronik, hemodialisis, kelelahan

Correspondence: Firman Prastiwi. Postgraduate Programme in Medical-surgical Nursing Faculty of Medecine Universitas Brawijaya Malang, Jl. Veteran Malang Tel.085345004999Email:firman.prastiwi@gmail.com

DOI: http://dx.doi.org/10.21776/ub.jkb.2021.031.04.12 


\section{INTRODUCTION}

The number of patients undergoing hemodialysis due to chronic kidney disease in 2010 increased by 2.62 million people worldwide, and it is predicted that it will double by 2030 (1). Data Report of the China Kidney Disease Network (CKNET) shows that in China the prevalence of hemodialysis increased rapidly by around 553,000 in 2015 (2). According to data from the Portuguese Nephrology Society, in 2015 there were 18,928 chronic kidney disease patients in Portugal, with 11,514 of them were enrolled in the dialysis program (3).

Although hemodialysis can help patients with kidney problems, long-term hemodialysis therapy can lead to complications and affect physical, psychological, social, spiritual, and emotional aspects that the individual cannot control $(4,5)$. Hemodialysis patients come with various problems such as sleep disorders, neurological problems, physiological problems, poor quality of life, anxiety, depression symptoms, and fatigue (6). The results of research conducted by Ali \& Taha (7) and Bossola et al (8) found that fatigue is one of the main complaints most often reported by patients with hemodialysis with a percentage of $78 \%$ to $83.8 \%$.

The fatigue experienced by patients undergoing hemodialysis can be due to several factors. According to the theory of unpleasant symptoms put forward by Lenz et al (9), fatigue can be influenced by physiological factors, psychological factors, and situational factors. Meanwhile, according to Artom et al (10) and Jham et al (11), demographic factors and socioeconomic factors can also contribute to the development of fatigue, thus when describing the factors that can affect fatigue - they include demography, physiology, socioeconomic, situational, and psychological. These factors can also contribute to further complications of fatigue.

Further complications of fatigue in patients on hemodialysis have been associated with poor quality of life and lower survival rates due to decreased physical and psychological activity $(12,13)$. Research by Abd El-Nasser Ali (14) and Vasilopoulou et al (15) found that hemodialysis patients who have significant problems with fatigue and depression can also affect the poor quality of life. Poor quality of life in hemodialysis patients can increase cardiovascular and suicide risks, therefore this will become a big problem if not given proper management $(13,16,17)$.

The importance of knowing the factors associated with fatigue is one of the strategies that can be used by health professionals in understanding and optimally applying interventions to reduce patient problems. Appropriate intervention can help patients manage fatigue thus it is important for improving the quality of life of patients with dialysis (12). However, the factors associated with fatigue in hemodialysis patients are still not comprehensively discussed, so this article aimed to determine the factors associated with fatigue in patients undergoing hemodialysis.

\section{METHOD}

\section{Design}

The design of this study was a systematic review that discussed the factors that cause fatigue in chronic kidney disease patients undergoing hemodialysis. The evaluation used in this study was the PRISMA checklist as a component to select the studies that have been found so that they could be adjusted to the objectives of this systematic review.

\section{Literature Search Strategy}

Study adapted to PRISMA guidelines. A data-based literature search was carried out in June 2020 and the articles selected were articles of reputable journals. Publication from 2011-2020 were include in this study. The literature has been systematically reviewed for empirical evidence regarding factors associated with fatigue in chronic kidney disease patients undergoing hemodialysis. Search using the Pubmed, ProQuest, EBSCO, and ScienceDirect databases used a combination of the keywords of chronic kidney disease, fatigue, and hemodialysis with the Boolean AND, OR, and NOT search methods to get related articles that match the objectives of the systematic review.

\section{Inclusion and Exclusion Criteria}

The determination of inclusion and exclusion criteria was adjusted based on PICOS (population, intervention, comparators, outcomes, and study design). The inclusion criteria in this systematic review were studies that focus on the population undergoing hemodialysis, studies that discuss factors associated with fatigue or interventions that can affect fatigue in chronic kidney disease patients undergoing hemodialysis, studies that explain the outcomes of factors that can influence fatigue and studies that focus on cross-sectional, randomized controlled clinical trial, prospective cohort study, dan non randomized control trial. While the exclusion criteria were studies that focus on populations other than chronic kidney disease patients, studies that had no association with causes of fatigue in patients undergoing hemodialysis, and studies that include articles review.

\section{Data Extraction}

Extraction of data and information was in the form of authors, research objectives, population selection, research design, data analysis techniques, educational content, samples, year of publication, and language used from each study so that the correct study will be extracted according to the research objectives.

\section{RESULTS}

\section{Characteristics of the Studies}

The results of a review of 23 articles in this study are related to factors associated with fatigue in chronic kidney disease patients undergoing hemodialysis (Table 1). The number of samples from the articles found ranged from 37 samples to 511 samples with a total of 3,633 samples. Of the selected articles the research was conducted in China $(26.08 \%, 6 / 23)$, Turkey $(13.04 \%, 3 / 23)$, United States (13.04\%, 3/23), Egypt (8.69\%, 2/23), Japan (8.69\%, 2/23), Italy $(8.69 \%, 2 / 23)$, Iran $(8.69 \%, 2 / 23)$, Netherlands $(4.34 \%, 1 / 23)$, United Kingdom (4.34\%, 1/23), and Greece $(4.34 \%, 1 / 23)$. The articles found were published from 2011 to 2020 and all were written in English. The articles found were original research, namely cross-sectional (73.9\%, 17/23), randomized controlled clinical trial $(13.04 \%, 3 / 23)$, prospective cohort study $(8.69 \%, 2 / 23)$, and non-randomized control trial (4.34\%, 1/23).

Factors that influence fatigue were found to be 
demographic factors $(52.17 \%, 12 / 23)$, physiological factors $(60.8 \%, 14 / 23)$, socioeconomic factors $(47.82 \%$, $11 / 23)$, situational factors $(43.47 \%, 10 / 23)$, and, psychological factors $(47.8 \%, 11 / 23)$. The measuring instruments used were the fatigue scale $(8.69 \%, 2 / 23)$, the fatigue severity scale (FSS) $(21.7 \%, 5 / 23)$, the fatigue sleepiness exhaustion scale $(4.34 \%, 1 / 23)$, SF-36 vitality subscale $(8.69 \%, 2 / 23)$, the fatigue questionnaire $(4.34 \%$, 1/23), FACIT-F Scale $(13.04 \%, 3 / 23)$, multidimensional fatigue inventory $(4.34 \%, 1 / 23)$, dialysis symptom fatigue index (DSI) $(8.69 \%, 2 / 23)$, the fatigue assessment scale $(4,34,2 / 23)$, revised piper's fatigue scale $(8,69 \%, 2 / 23)$, hemodialysis patients fatigue Scale $(4.34 \%, 1 / 23)$, lowa fatigue scale (IFS) $(4.34 \%, 1 / 23)$, and the piper's fatigue scale $(4.34 \%, 1 / 23)$.

\section{Study Selection}

Based on the results of literature searches through publications in four databases and using keywords, the researchers found 3575 articles that matched the keywords. Then the articles were checked for duplication and it was found 759 duplicated articles so they were excluded, and the remaining was 2816 articles. The researchers then conducted a screening based on the title and abstract of the study and obtained 82 articles that fit the objective of this study; these 82 articles were then screened in full text. The feasibility assessment of 82 articles based on the text as a whole and conformity to the eligibility criteria obtained 23 articles that can be used in this systematic review. The results of the study articles selection can be illustrated in the Flow Diagram using the PRISMA selection process below:

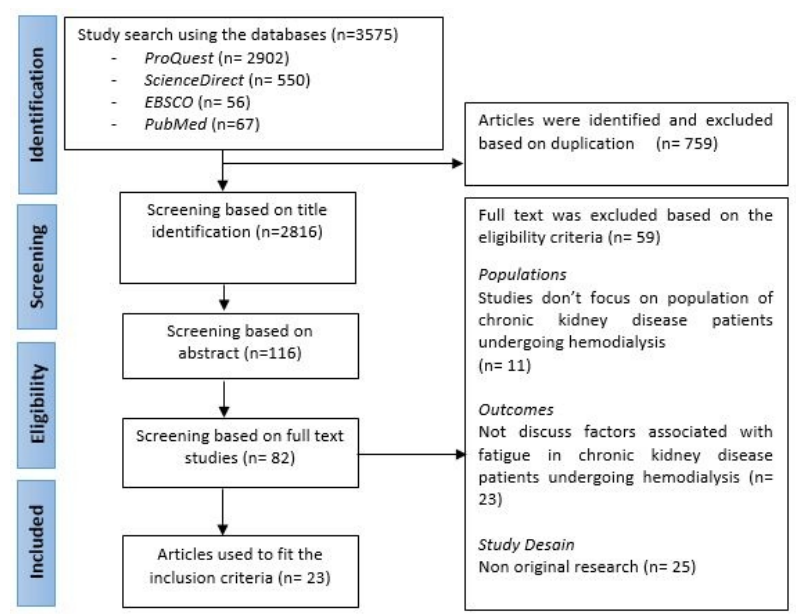

Image 1. Flowchart of articles selected on the systematic review, selection process using PRISMA

\section{Demographic Factors}

Based on the results of the study, it was found that demographic factors such as age that is more than 50 years, female gender, married status, lower education are associated with higher levels of fatigue in patients (18-21). Then, other factors such as black race and unemployed status have higher rates associated with the problem of fatigue $(18,19)$. However, there is not enough evidence and research controversy remains to describe the association of these factors with fatigue in patients undergoing hemodialysis. Several studies did not find a relationship between age, gender, marital status, occupation, race, and education with the level of fatigue in hemodialysis patients with a p-value $>0.05$ $(8,17,19,22,23)$. However, other studies found a relationship between gender, marital status, occupation, and education with the level of fatigue with a $p$-value $<0.05(18,21,24)$.

\section{Physiological Factors}

The results of the analysis showed that patients who had sleep disorders (7), HB levels of $<10 \mathrm{mg} / \mathrm{dl}$ (21), an average BUN of $44.1 \mathrm{mg} / \mathrm{dl}(25)$, mean hematocrit of $35 \%$, mean albumin of $3.9 \mathrm{~g} / \mathrm{dl}$, mean creatinine of $9.7 \mathrm{mg} / \mathrm{dl}$, mean calcium of $9.1 \mathrm{mg} / \mathrm{dl}(8)$, an average IL- 6 with a value of $5.1 \mathrm{pg} / \mathrm{Ml}$, an average BMI value of 28.5 (19) had a higher level of fatigue. However, there were differences in research findings regarding physiological factors associated with fatigue. There are studies that found there is no relationship between BMI ( $r=0.019$, $p$-value 0.833 ), albumin ( $r=0.071, p$-value 0.567$)$, hemoglobin ( $r=$ 0.174 , p-value 0.053) (26), calcium (coefficient correlation of 0.182 , $p$-value 0.084 ) (27), sleep patterns ( $p$ $>0.05)$ (7), creatinine ( $p$-value 0.807$)$, hematocrit ( $p$ value 1.000$)(8)$, and bilirubin $(p<0.05)(28)$ with fatigue. However, other studies found that there is a relationship between albumin (correlation coefficient of 0.223 , pvalue 0.040 ), creatinine (correlation coefficient of 0.347 , p-value 0.001 ), urea (correlation coefficient of $0.322, p-$ value 0.012 ), and IL-6 (correlation coefficient of 0.660 , $p$ value 0.001 ) (27), BMI $p$-value $<0.05)(29)$, hemoglobin ( $p$ value 0.048$)$, and sleep quality (p-value 0.003 ) (19) with fatigue.

\section{Socioeconomic Factors}

In general, several studies found that low physical activity (18), smokers and ex-smokers (19), living in urban areas (23), low family income (24), and families with nuclear family structures and difficult economic status (17) are associated with higher levels of fatigue. There are studies that found there is no relationship between physical activity carried out for 2 months (p-value 0.24) (30), smoking status ( $p$-value 0.24$)(19)$, family structure ( $p$ value 0.13 ), tea consumption ( $p$-value 0.321 ), coffee consumption ( $p$-value 0.38 ), smoking ( $p$-value 0.74$)$, and alcohol consumption ( $p$-value 0.276) (17) with fatigue. However, other studies found that there is a relationship between physical activity ( $p$-value $<0.05)(18,29)$, living area ( $p$-value 0.002 ) (23), treatment method cost ( $p$-value $0.001)$, family income ( $p$-value 0.001) (24), economic status ( $p$-value 0.006) (17) with fatigue.

\section{Situational Factors}

In situational factors, it was found that the length of time in undergoing hemodialysis with an average of above 6 years, has comorbid diseases $(8,18,26)$ such as cardiovascular and diabetes mellitus (26), the frequency of hemodialysis of 3 times a week $(22,24)$, has disease complications $(21,24)$ have a higher rate of fatigue, but the relationship with fatigue is not clear enough. There are studies that found there is no relationship between comorbid diseases ( $p$-value 0.938) (8), length of time in undergoing hemodialysis ( $r=-0.154$, $p$-value 0.086$)$, diabetes mellitus ( $r=0.128, p$-value 0.157$)$, the frequency of dialysis $(F=$ 2.156, $p$-value 0.119) (22), and cardiovascular disease ( $r=$ $0.151, p$-value 0.092 ) (26) with fatigue in hemodialysis 
patients. However, other studies found that there is a relationship between cardiovascular disease (standard error of 2.15, p-value 0.01) (19), comorbid diseases ( $p$ value 0.001 ) (17), the frequency of dialysis (mean 260.00, p-value <0.001) (24) with fatigue.

\section{Psychological Factors}

The psychological factors most commonly found in cases of fatigue are depression and anxiety. Moderate to severe depression levels were found to be in line with the incidence of fatigue $(7,27)$. Meanwhile, the higher the anxiety score, the higher the symptoms of fatigue $(20,24)$. There is a study that found that there is no relationship between depression ( $p$-value 0.07 ) and fatigue. However, other studies found there is a relationship between anxiety and depression ( $p$-value <0.05) $(20,29)$ with fatigue.

\section{DISCUSSION}

Demographic factors such as age that is more than 50 years, lower education, female gender, and married status are associated with have high levels of fatigue $(17,24)$. However, there is still inconclusive and insufficient evidence because there are still differences in research findings. Regarding age, there are many convincing findings that found the increase of age will contribute to fatigue $(17,18,21)$. This is because patients with older age experience decreased physical function, especially in the kidneys, which is a triggering factor for fatigue. Regarding gender, most studies have found no association with fatigue, this may be due to the large sample size from several studies and the unbalanced distribution between women and men so that this needs to be further proven. Varied results are found in educational status and marital status, so further exploration is needed to obtain consistent results.

Table 1. Summary of included studies

\begin{tabular}{|c|c|c|c|c|c|}
\hline $\begin{array}{c}\text { First } \\
\text { Authors }\end{array}$ & Cause Factors & Tools & Study Design & $n$ & Result \\
\hline \multirow[t]{2}{*}{$\begin{array}{l}\text { Bai } \\
(2015) \\
(18)\end{array}$} & $\begin{array}{l}\text { Demographics: Age, } \\
\text { gender, education, marital } \\
\text { status, employment status }\end{array}$ & \multirow[t]{2}{*}{ The Fatigue Scale } & \multirow[t]{2}{*}{ Cross-sectional } & \multirow[t]{2}{*}{193} & \multirow{2}{*}{$\begin{array}{l}\text { There was relationship between age, } \\
\text { employment status, marital status, physical } \\
\text { activity with fatigue. } \\
\text { There was no relationship between sex, } \\
\text { education, length of undergoing } \\
\text { hemodialysis, comorbid disease with fatigue }\end{array}$} \\
\hline & $\begin{array}{ll}\text { - } & \text { Socio-economy: physical } \\
\text { activity } & \\
\text { - } & \text { Situational: comorbid } \\
\text { disease, long undergoing } \\
\text { hemodialysis }\end{array}$ & & & & \\
\hline \multirow[t]{2}{*}{$\begin{array}{l}\text { Ali (2017) } \\
\text { (7) }\end{array}$} & $\begin{array}{ll}\text { - } & \begin{array}{l}\text { Demographics: age } \text { and } \\
\text { education }\end{array} \\
\text { - } & \text { Physiological: } \\
\text { patterns } & \text { Sleep }\end{array}$ & \multirow[t]{2}{*}{$\begin{array}{l}\text { Fatigue Severity } \\
\text { Scale (FSS) }\end{array}$} & \multirow[t]{2}{*}{ Cross-sectional } & \multirow[t]{2}{*}{105} & \multirow{2}{*}{$\begin{array}{l}\text { There was no relationship between sleep } \\
\text { patterns, age, education and depression } \\
\text { with fatigue } \\
\text { However, based on several dimensions of } \\
\text { sleep pattern factors, there is a relationship } \\
\text { between sleep during the day and sleep } \\
\text { latency with fatigue }\end{array}$} \\
\hline & - $\quad$ Psychological: Depression & & & & \\
\hline \multirow{2}{*}{$\begin{array}{l}\text { Abdel- } \\
\text { Kader } \\
(2014) \\
(25)\end{array}$} & \multirow{2}{*}{$\begin{array}{l}\text { Physiological: } \quad \text { sleep } \\
\text { patterns } \\
\text { Psychological: anxiety, } \\
\text { stress, mood }\end{array}$} & \multirow[t]{2}{*}{$\begin{array}{l}\text { Fatigue Sleepiness } \\
\text { Exhaustion Scale }\end{array}$} & \multirow[t]{2}{*}{$\begin{array}{l}\text { Prospective } \\
\text { Cohort Study }\end{array}$} & \multirow[t]{2}{*}{55} & $\begin{array}{l}\text { There was relationship between anxiety and } \\
\text { mood with fatigue. }\end{array}$ \\
\hline & & & & & $\begin{array}{l}\text { There was no relationship between sleep } \\
\text { patterns and stress with fatigue }\end{array}$ \\
\hline \multirow{3}{*}{$\begin{array}{l}\text { Bossola } \\
(2018) \\
(8)\end{array}$} & $\begin{array}{l}\text { Demographics: Age, } \\
\text { gender }\end{array}$ & \multirow[t]{3}{*}{$\begin{array}{l}\text { SF-36 Vitality } \\
\text { Subscale }\end{array}$} & \multirow[t]{3}{*}{ Cross-sectional } & \multirow[t]{3}{*}{137} & \multirow{3}{*}{$\begin{array}{l}\text { There was relationship between the level of } \\
\text { anxiety and fatigue } \\
\text { There was no relationship between } \\
\text { hemoglobin, albumin, creatinine, } \\
\text { hematocrit, calcium, age, sex, comorbid } \\
\text { disease and length of undergoing } \\
\text { hemodialysis with fatigue. }\end{array}$} \\
\hline & $\begin{array}{l}\text { Physiological: hemoglobin, } \\
\text { albumin, creatinine, } \\
\text { hematocrit, calcium }\end{array}$ & & & & \\
\hline & $\begin{array}{l}\text { Situational: comorbid } \\
\text { disease, length of } \\
\text { undergoing hemodialysis } \\
\text { - } \begin{array}{l}\text { Psychological: the level of } \\
\text { anxiety }\end{array}\end{array}$ & & & & \\
\hline $\begin{array}{l}\text { Chilcot } \\
(2016) \\
(29)\end{array}$ & $\begin{array}{ll}- & \text { Physiology: Body Mass } \\
\text { Index (BMI) } \\
\text { - } \quad \text { Socio-economy: physical } \\
\text { exercise } \\
\text { - } \quad \begin{array}{l}\text { Psychological: anxiety and } \\
\text { depression }\end{array} \\
\end{array}$ & $\begin{array}{l}\text { Fatigue Severity } \\
\text { Scale (FSS) }\end{array}$ & Cross-sectional & 174 & $\begin{array}{l}\text { There was relationship between BMI } \\
\text { physical exercise, anxiety and depression } \\
\text { with fatigue }\end{array}$ \\
\hline \multirow{4}{*}{$\begin{array}{l}\text { Bossola } \\
(2014) \\
(27)\end{array}$} & $\begin{array}{l}\text { Demographics: Age, } \\
\text { gender, marital status }\end{array}$ & \multirow[t]{4}{*}{$\begin{array}{l}\text { SF-36 Vitality } \\
\text { Subscale }\end{array}$} & \multirow[t]{4}{*}{ Cross-sectional } & \multirow[t]{4}{*}{100} & \multirow{4}{*}{$\begin{array}{l}\text { There was relationship between age } \\
\text { anxiety, albumin, creatinine, depression } \\
\text { urea and IL- } 6 \text { with fatigue }\end{array}$} \\
\hline & $\begin{array}{l}\text { - Physiology: Body Mass } \\
\text { Index (BMI), albumin, }\end{array}$ & & & & \\
\hline & $\begin{array}{lr}\begin{array}{l}\text { creatinine, } \\
\text { hemoglobin, }\end{array} & \text { calcium, } \\
\text { interlukin } 6 \text { (IL-6) } & \end{array}$ & & & & \\
\hline & $\begin{array}{l}\text { Situational: length of } \\
\text { undergoing hemodialysis } \\
\text { Psychological: depression, } \\
\text { anxiety }\end{array}$ & & & & \\
\hline $\begin{array}{l}\text { Fukuda } \\
(2015) \\
(31)\end{array}$ & Physiological: Nutrition & $\begin{array}{l}\text { The Fatigue } \\
\text { Questionnare }\end{array}$ & $\begin{array}{l}\text { Randomized } \\
\text { controlled } \\
\text { clinical trial }\end{array}$ & 173 & $\begin{array}{l}\text { There was effect of nutrition on fatigue in } \\
\text { hemodialysis patients }\end{array}$ \\
\hline
\end{tabular}


Table 1. Summary of included studies (Cont.)

\begin{tabular}{|c|c|c|c|c|c|}
\hline $\begin{array}{c}\text { First } \\
\text { Authors }\end{array}$ & Cause Factors & Tools & Study Design & $n$ & Result \\
\hline $\begin{array}{l}\text { Jham } \\
(2013) \\
(19)\end{array}$ & $\begin{array}{l}\text { Demographics: age, } \\
\text { gender, race, education, } \\
\text { marital status, } \\
\text { employment status } \\
\text { Physiological: sleep } \\
\text { patterns, albumin, BMI, } \\
\text { hemoglobin, albumin } \\
\text { - Socioeconomic: smoking } \\
\text { status } \\
\text { Situational: cardiovascular } \\
\text { disease, diabetes mellitus } \\
\text { Psychological: depression }\end{array}$ & FACIT-F Scale & Cross-sectional & 173 & $\begin{array}{l}\text { There was relationship between albumin } \\
\text { levels, hemoglobin, sleep patterns, albumin, } \\
\text { cardiovascular disease and depression with } \\
\text { fatigue } \\
\text { There was no relationship between age, sex, } \\
\text { race, education, marital status, employment } \\
\text { status, diabetes mellitus, BMI, smoking } \\
\text { status with fatigue. }\end{array}$ \\
\hline $\begin{array}{l}\text { Salehi } \\
(2020) \\
(30)\end{array}$ & $\begin{array}{l}\text { - } \begin{array}{l}\text { Socio-economy: physical } \\
\text { exercise }\end{array} \\
\end{array}$ & $\begin{array}{c}\text { Multi } \\
\text { dimensional } \\
\text { Fatigue Inventory }\end{array}$ & $\begin{array}{l}\text { Randomized } \\
\text { controlled } \\
\text { clinical trial }\end{array}$ & 37 & $\begin{array}{l}\text { There was no effect of giving physical } \\
\text { exercise in the first and second months on } \\
\text { fatigue in hemodialysis patients } \\
\text { There was effect of physical exercise at the } \\
\text { third month on fatigue in hemodialysis } \\
\text { patients }\end{array}$ \\
\hline $\begin{array}{l}\text { Hintistan } \\
(2018) \\
(22)\end{array}$ & 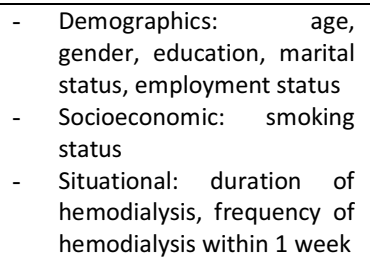 & $\begin{array}{l}\text { Dialysis Symptom } \\
\text { Index Fatigue } \\
\text { (DSI) }\end{array}$ & Cross-sectional & 194 & $\begin{array}{l}\text { There was relationship between gender, } \\
\text { marital status, education, employment } \\
\text { status, with fatigue } \\
\text { There was no relationship between age, } \\
\text { smoking status, duration of hemodialysis, } \\
\text { frequency of hemodialysis, with fatigue }\end{array}$ \\
\hline $\begin{array}{l}\text { Royani } \\
(2017) \\
(20)\end{array}$ & 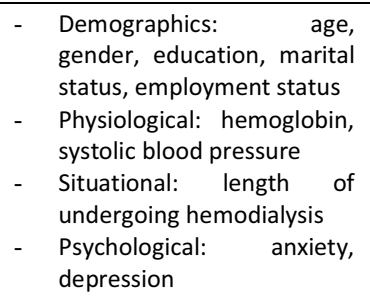 & $\begin{array}{l}\text { Fatigue Severity } \\
\text { Scale (FSS) }\end{array}$ & Cross-sectional & 165 & $\begin{array}{l}\text { There was relationship between anxiety and } \\
\text { depression with fatigue } \\
\text { There was no relationship between } \\
\text { hemoglobin levels, systolic blood pressure, } \\
\text { length of undergoing hemodialysis, age, sex, } \\
\text { education, marital status, employment } \\
\text { status and fatigue. }\end{array}$ \\
\hline $\begin{array}{l}\text { Sheshad } \\
(2019) \\
(32)\end{array}$ & $\begin{array}{l}\text { - Socio-economy: physical } \\
\text { activity }\end{array}$ & $\begin{array}{l}\text { Dialysis Symptom } \\
\text { Index Fatigue } \\
\text { (DSI) }\end{array}$ & Cross-sectional & 48 & $\begin{array}{l}\text { There was relationship between physical } \\
\text { activity with fatigue }\end{array}$ \\
\hline $\begin{array}{l}\text { Kodama } \\
(2020) \\
(26)\end{array}$ & 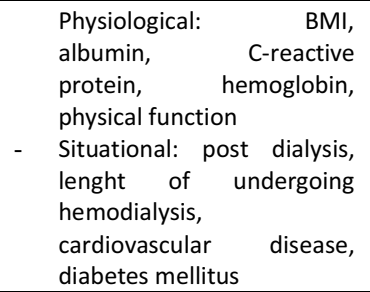 & The Fatigue Scale & Cross sectional & 126 & $\begin{array}{l}\text { There was relationship between post } \\
\text { dialysis and physical function with fatigue } \\
\text { There was no correlation between length of } \\
\text { undergoing hemodialysis, diabetes mellitus, } \\
\text { cardiovascular disease, BMI, albumin, C- } \\
\text { reactive protein, hemoglobin with fatigue. }\end{array}$ \\
\hline $\begin{array}{l}\text { Wang } \\
(2015) \\
(33)\end{array}$ & - Psychological: depression & FACIT-F Scale & Cross-sectional & 187 & $\begin{array}{l}\text { There was relationship between depression } \\
\text { with fatigue }\end{array}$ \\
\hline $\begin{array}{l}\text { Zyga } \\
(2015) \\
(23)\end{array}$ & $\begin{array}{ll}- & \text { Demographics: education } \\
\text { - } & \text { Socio-economic: Residence }\end{array}$ & $\begin{array}{c}\text { The Fatigue } \\
\text { Assessment Scale }\end{array}$ & Cross-sectional & 129 & $\begin{array}{l}\text { There was relationship between residence } \\
\text { and work with fatigue } \\
\text { There was no relationship between } \\
\text { education with fatigue }\end{array}$ \\
\hline $\begin{array}{l}\text { Zuo } \\
(2018) \\
(24)\end{array}$ & 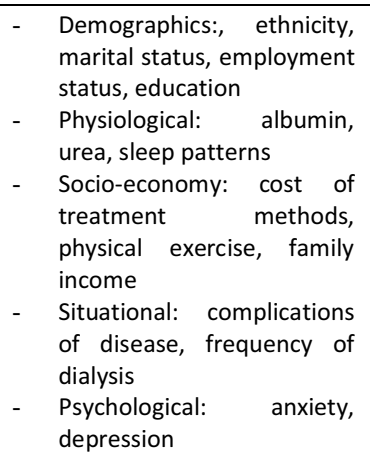 & $\begin{array}{l}\text { Revised Piper's } \\
\text { Fatigue Scale }\end{array}$ & Cross-sectional & 511 & $\begin{array}{l}\text { There was relationship between ethnicit } \\
\text { marital status, employment status, } \\
\text { education, cost of treatment methods, } \\
\text { physical exercise, complications of disease, } \\
\text { frequency of dialysis, anxiety, depression, } \\
\text { family income, albumin, urea, sleep patterns } \\
\text { with fatigue }\end{array}$ \\
\hline
\end{tabular}


Table 1. Summary of included studies (Cont.)

\begin{tabular}{|c|c|c|c|c|c|}
\hline $\begin{array}{c}\text { First } \\
\text { Authors }\end{array}$ & Cause Factors & Tools & Study Design & $n$ & Result \\
\hline $\begin{array}{l}\text { Yang } \\
(2017) \\
(21)\end{array}$ & $\begin{array}{l}\text { Demographics:, age, } \\
\text { employment status, } \\
\text { education, marital status } \\
\text { Physiological: sleep } \\
\text { disorders, hemoglobin, } \\
\text { albumin } \\
\text { - Situational: complications } \\
\text { of disease, frequency of } \\
\text { dialysis, length of time on } \\
\text { hemodialysis }\end{array}$ & $\begin{array}{l}\text { Revised Piper's } \\
\text { Fatigue Scale- } \\
\text { Chinese Version }\end{array}$ & Cross-sectional & 130 & $\begin{array}{l}\text { There was relationship between age, } \\
\text { occupation, education, sleep disorders, } \\
\text { albumin, disease complications, dialysis } \\
\text { frequency with fatigue } \\
\text { There was no relationship between marital } \\
\text { status, lenght of undergoing hemodialysis } \\
\text { and hemoglobin levels with fatigue }\end{array}$ \\
\hline $\begin{array}{l}\text { Wang } \\
(2016) \\
(17)\end{array}$ & 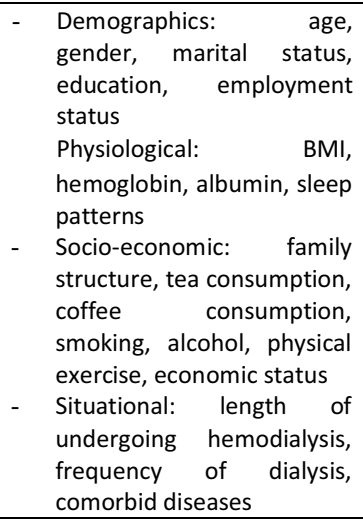 & FACIT-F Scale & Cross-sectional & 345 & $\begin{array}{l}\text { There was relationship between age, } \\
\text { physical exercise, economic status, } \\
\text { employment status, comorbid diseases, } \\
\text { sleep patterns with fatigue } \\
\text { There was no relationship between gender, } \\
\text { BMI, marital status, family structure, tea } \\
\text { consumption, coffee consumption, alcohol } \\
\text { smoking, education, length of undergoing } \\
\text { hemodialysis, dialysis frequency, } \\
\text { hemoglobin, albumin with fatigue. }\end{array}$ \\
\hline $\begin{array}{l}\text { Wu } \\
(2014) \\
(34)\end{array}$ & $\begin{array}{ll}\text { - } & \begin{array}{l}\text { Situational: } \\
\text { exercise }\end{array}\end{array}$ & $\begin{array}{l}\text { Haemodialysis } \\
\text { Patients Fatigue } \\
\text { Scale }\end{array}$ & $\begin{array}{l}\text { Non Random } \\
\text { Control Trial }\end{array}$ & 172 & $\begin{array}{l}\text { There was effect of physical exercise on } \\
\text { fatigue in patients undergoing hemodialysis }\end{array}$ \\
\hline $\begin{array}{l}\text { Huisman } \\
(2011) \\
(28)\end{array}$ & $\begin{array}{l}\text { - } \begin{array}{l}\text { Physiological: } \\
\text { albumin, }\end{array} \\
\text { creatinine } \\
\text { - } \begin{array}{l}\text { Psycholobilirubin, } \\
\text { anxiety }\end{array}\end{array}$ & $\begin{array}{l}\text { Fatigue Severity } \\
\text { Scale (FSS) }\end{array}$ & $\begin{array}{l}\text { Prospective } \\
\text { Cohort Study }\end{array}$ & 75 & $\begin{array}{l}\text { There was relationship between depression } \\
\text { and anxiety with fatigue } \\
\text { There was no relationship between levels of } \\
\text { hemoglobin, albumin, bilirubin, creatinine } \\
\text { with fatigue }\end{array}$ \\
\hline $\begin{array}{l}\text { Turk } \\
(2018) \\
(35)\end{array}$ & $\begin{array}{l}\text { - } \begin{array}{l}\text { Situational : restless leg } \\
\text { syndrome }\end{array} \\
\end{array}$ & $\begin{array}{l}\text { Fatigue Severity } \\
\text { Scale (FSS) }\end{array}$ & Cross-sectional & 220 & $\begin{array}{l}\text { There was relationship between restless leg } \\
\text { syndrome and fatigue }\end{array}$ \\
\hline $\begin{array}{l}\text { Soliman } \\
(2015) \\
(36)\end{array}$ & $\begin{array}{l}\text { - } \begin{array}{l}\text { Demographics: } \\
\text { marital status, residence, }\end{array} \\
\begin{array}{l}\text { education, employment } \\
\text { status }\end{array} \\
\text { - } \begin{array}{l}\text { Socio-economy: Physical } \\
\text { exercise }\end{array} \\
\end{array}$ & $\begin{array}{l}\text { lowa Fatigue } \\
\text { Scale (IFS) }\end{array}$ & $\begin{array}{l}\text { Randomized } \\
\text { controlled } \\
\text { clinical trial }\end{array}$ & 30 & $\begin{array}{l}\text { There was relationship between physical } \\
\text { exercise with fatigue } \\
\text { There was no relationship between gender, } \\
\text { marital status, residence, education, } \\
\text { employment status with fatigue }\end{array}$ \\
\hline $\begin{array}{l}\text { Karakan } \\
(2011) \\
(37)\end{array}$ & $\begin{array}{llr}- & \text { Physiological: } & \text { Serum } \\
\text { potassium, } & \text { Serum } \\
\text { phosphorus } & \\
\text { - } & \text { Psychological: Depression } \\
\end{array}$ & $\begin{array}{l}\text { The Piper's } \\
\text { Fatigue Scale }\end{array}$ & Cross-sectional & 154 & $\begin{array}{l}\text { There was relationship between serum } \\
\text { potassium, serum phosphorus and } \\
\text { depression with fatigue }\end{array}$ \\
\hline
\end{tabular}

Physiological factors associated with disturbed levels of hemoglobin, BUN, hematocrit, creatinine, IL-6, and BMI levels are associated with factors of fatigue $(8,19,25)$. However, some research findings are still different related to factors related to fatigue. The state of anemia is related to fatigue in general due to a lack of oxygen supply that enters the cells, which is a trigger to fatigue. Individuals with chronic kidney disease have a target of maintaining hemoglobin levels of 10 to $11.5 \mathrm{~g} / \mathrm{dL}$ (38). Increased levels of BUN and creatinine can affect fatigue due to accumulated body metabolic waste which can trigger a state of malaise (39). Increased IL-6 is also associated with fatigue but research by Bossola et al (40) found that there was no significant relationship between IL- 6 levels and fatigue, however, in general serum IL-6 levels were proven to increase in patients with fatigue. The lack of statistical significance can be attributed to the small sample size. Meanwhile, BMI is associated with excess body weight that triggers fatigue in chronic kidney disease patients undergoing hemodialysis (39).

The socioeconomic factors most often associated with fatigue are low physical activity and a history of smoking and alcohol consumption $(17,18,22,29)$. Most of the studies found that decreased physical activity is closely related to fatigue. Several studies found the effect of physical activity on reducing levels of fatigue in patients undergoing hemodialysis $(34,36)$. Physical activity can be associated with increased blood flow to the muscles, increasing the number of capillaries and increasing the area and surface of the capillaries so as to reduce fatigue in patients. Then related to a history of smoking and alcohol consumption in general, there are higher numbers of patients experiencing fatigue. However, there is no strong evidence yet and there are still differences from some of the research results, thus it remains to be explored further $(17,22)$. 
In situational factors, there are several studies that reveal that the length of time in undergoing hemodialysis with more than 5 years, has comorbid diseases and complications such as cardiovascular disease and diabetes mellitus, has more frequency of hemodialysis, and has disease complications $(8,18,21,24,26)$ have a higher incidence of fatigue in patients on hemodialysis. However, the mechanism mentioned from several studies related to situational factors with the incidence of fatigue is still unclear, so this still needs to be further proven. In general, hemodialysis patients report higher levels of fatigue when they have been on hemodialysis for a long time which is associated with intradialysis hypotension, whereas patients who have comorbid disease will add more burden and stress to the individual. Patients with stage 4 and 5 of kidney disease who suffer from hypertension and diabetes mellitus have a higher rate of fatigue than patients who do not have comorbidities (39).

The most common psychological factors found in research are depression and anxiety $(20,24,33)$. Most of the studies found that there is a relationship between psychological factors and fatigue, although there were still differences in the results of the research which might be due to the relatively small sample factor. In general, depression and anxiety are associated with peripheral activation of immune-inflammatory pathways that can contribute to neurological inflammation and ongoing neuroprogressive changes including decreased neuroplasticity, neurogenesis, increased neurodegeneration, and reduced expression of neurotransmitters (e.g., serotonin, noradrenaline). Therefore, It has been shown that

\section{REFERENCES}

1. Kidney Disease Improving Global Outcomes (KDIGO). Global Burden of Dialysis Initiation (nd Continuation). Madrid: Controversies Conference on Dialysis Initiation, Modality Choice \& Prescription. (Online) 2018. https://kdigo.org/wpcontent/uploads/2017/02/Jha_KDIGO-Dialysis-Jan2018.pdf.

2. Wang F, Yang C, Long J, et al. Executive Summary for the 2015 Annual Data Report of the China Kidney Disease Network (CK-NET). Kidney International. 2019; 95(3): 501-505.

3. Olim MF, Guadalupe S, Mota F, Fragoso P, and Ribeiro S. Sociographic Profile of Hemodialysis Patients in Portugal. National Kidney Foundation Journal of Nephrology Social Work. 2018; 42(1): 9-20.

4. Reza Afazel M, Aghajani M, and Morassaie F. The Effects of Spiritual Counseling on the Hope in Hemodialysis Patients: A Clinical Trial Study. Life Science Journal. 2013; 10: 293-297.

5. Tavassoli N, Darvishpour A, Mansour-Ghanaei R, and Atrkarroushan Z. A Correlational Study of Hope and Its Relationship with Spiritual Health on Hemodialysis Patients. Journal of Education and Health Promotion. 2019; 8: 1-6.

6. Sakkas GK and Karatzaferi C. Hemodialysis Fatigue: Just "Simple" Fatigue or a Syndrome on Its Own Right? Frontiers in Physiology. 2012; 3: 1-4.

7. Ali $\mathrm{HH}$ and Taha NM. Fatigue, Depression and Sleep activated immune-inflammatory pathways such as interleukin-6 (IL-6) can contribute to the fatigue experienced by individuals with chronic kidney disease $(27,41)$.

The implication that can be learned from the factors that cause fatigue in patients undergoing hemodialysis is to facilitate health practitioners to manage fatigue, especially those associated with the most dominant causative factor. Besides, health practitioners can identify the patient population undergoing hemodialysis who have the most potential to experience fatigue which can result in a decrease in quality of life and increase the risk of death to make sure that prevention can be carried out more quickly so as not to cause more complex problems.

The study's findings concluded that there were several factors contributing to fatigue, but there were still some discrepancies between the findings, which may be attributed to variations in respondent characteristics, sample size, and study design methods, necessitating further research to determine the causative factors of fatigue. There is much to learn about fatigue in patients undergoing hemodialysis, including causal factors, assessment of severity, and effective management of fatigue so it is important to study fatigue-related issues more specifically to apply to patients. Further identification of fatigue can be used as a benchmark to determine appropriate interventions that can be provided by health workers to produce fatigue management following the dominant causative factors that can be applied to patients undergoing hemodialysis.

Disturbance among Hemodialysis Patients. IOSR Journal of Nursing and Health Science. 2017; 6(3): 61-69.

8. Bossola M, Di Stasio E, Marzetti E, De Lorenzis K, Pepe $\mathrm{G}$, and Vulpio C. Fatigue is Associated with High Prevalence and Severity of Physical and Emotional Symptoms in Patients on Chronic Hemodialysis. International Urology and Nephrology. 2018; 50(7): 1341-1346.

9. Lenz ER, Gift A, Pugh LC, and Milligan RA. Unpleasant Symptoms. In: Peternon SJ and Bredow TS (Eds). Middlerange Theories: Application to Nursing Research. New York: Wolters Kluwer; 2013: p. 68-81.

10. Artom M, Moss-Morris R, Caskey F, and Chilcot J. Fatigue in Advanced Kidney Disease. Kidney International. 2014; 86(3): 497-505.

11. Jhamb M, Argyropoulos C, Steel JL, et al. Correlates and Outcomes of Fatigue among Incident Dialysis Patients. Clinical Journal of the American Society of Nephrology. 2009; 4(11): 1779-1786.

12. Horigan AE, Schneider SM, Docherty S, and Barroso J. The Experience and Self Management of Fatigue in Patients on Hemodialysis. Nephrology Nursing Journal: Journal of the American Nephrology Nurses' Association. 2013; 40 (2): 113-122.

13. Kim B and Kim J. Influence of Uncertainty, Depression, and Social Support on Self-Care Compliance in Hemodialysis Patients. Therapeutics and Clinical Risk Management. 2019; 15: 1243-1251.

14. El-Nasser Ali GA. Impact of Fatigue and Sleep Quality 
upon the Quality of Life of Haemodialysis Recipient Patients. Kufa Journal for Nursing Sciences. 2015; 5(2): 1-13.

15. Vasilopoulou C, Bourtsi E, Giaple S, Koutelekos I, Theofilou P, and Polikandrioti M. The Impact of Anxiety and Depression on the Quality of Life of Hemodialysis Patients. Global Journal and Health Science. 2016; 8(1): 45-55.

16. Pu J, Jiang Z, Wu W, et al. Efficacy and Safety of Intradialytic Exercise in Haemodialysis Patients: A Systematic Review and Meta-Analysis. BMJ Open. 2019; 9(1): 1-12.

17. Wang SY, Zang XY, Fu SH, et al. Factors Related to Fatigue in Chinese Patients with End-Stage Renal Disease Receiving Maintenance Hemodialysis: A Multi-Center Cross-Sectional Study. Renal Failure. 2016; 38(3): 442-450.

18. Bai YL, Lai $\mathrm{LY}$, Lee BO, Chang YY, and Chiou CP. The Impact of Depression on Fatigue in Patients with Haemodialysis: A Correlational Study. Jornal of Clinical Nursing. 2015; 24(13-14): 2014-2022.

19. Jhamb M, Liang K, Yabes J, et al. Prevalence and Correlates of Fatigue in Chronic Kidney Disease and End-Stage Renal Disease: Are Sleep Disorders a Key to Understanding Fatigue? American Journal of Nephrology. 2013; 38(6): 489-495.

20. Royani Z, Roohi G, Sabzi Z, Mancheri H, and Mollaei E. Relationship between Fatigue and Physical, Psychological and Situational Factors in Hemodialysis Patients. Journal of Research Development in Nursing and Midwifery. 2017; 14(2): 65-71.

21. Yang PC and Lu YY. Predictors of Fatigue among Female Patients on Hemodialysis. Nephrology Nursing Journal: Journal of the American Nephrology Nurses' Association. 2017; 44(6): 533-539.

22. Hintistan S and Deniz A. Evaluation of Symptoms in Patients Undergoing Hemodialysis. Bezmialem Science. 2018; 6(2): 112-118.

23. Zyga S, Alikari V, Sachlas A, et al. Assessment of Fatigue in End Stage Renal Disease Patients Undergoing Hemodialysis: Prevalence and Associated Factors. Medical Archives. 2015; 69(6): 376-380.

24. Zuo M, Tang J, Xiang M, Long Q, Dai J, and Hu X. Relationship Between Fatigue Symptoms and Subjective and Objective Indicators in Hemodialysis Patients. International Urology and Nephrology. 2018; 50(7): 1329-1339.

25. Abdel-Kader K, Jhamb M, Mandich LA, et al. Ecological Momentary Assessment of Fatigue, Sleepiness, and Exhaustion in ESKD. BioMed Central Nephrology. 2014; 15(1): 1-8.

26. Kodama H, Togari T, Konno YK, et al. A New Assessment Scale For Post-Dialysis Fatigue In Hemodialysis Patients. Renal Replacement Therapy. 2020; 6(1): 4-11.

27. Bossola M, Di Stasio E, Giungi S, Rosa F, and Tazza L. Fatigue is Associated with Serum Interleukin-6 Levels and Symptoms of Depression in Patients on Chronic
Hemodialysis. Journal of Pain and Symptom Management. 2014; 49(3): 578-585.

28. Huisman-De Waal G, Bazelmans E, Van Achterberg T, et al. Predicting Fatigue In Patients Using Home Parenteral Nutrition: A Longitudinal Study. International Journal of Behavioral Medicine. 2011; 18(3): 268-276.

29. Chilcot J, Moss-Morris R, Artom M, et al. Psychosocial and Clinical Correlates of Fatigue in Haemodialysis Patients: The Importance of Patients' IIIness Cognitions and Behaviours. International Journal of Behavioral Medicine. 2016; 23(3): 271-281.

30. Salehi F, Dehghan M, Shahrbabaki PM, and Ebadzadeh MR. Effectiveness of Exercise on Fatigue in Hemodialysis Patients: A Randomized Controlled Trial. BMC Sports Science, Medicine, \& Rehabilitation. 2020; 12(1): 1-10.

31. Fukuda S, Koyama $\mathrm{H}$, Kondo $\mathrm{K}$, et al. Effects of Nutritional Supplementation on Fatigue, and Autonomic and Immune Dysfunction in Patients with End-Stage Renal Disease: A Randomized, DoubleBlind, Placebo-Controlled, Multicenter Trial. PLoS One. 2015; 10(3): 1-16.

32. Sheshadri A, Kittiskulnam P, Johansen KL. Higher Physical Activity is Associated with Less Fatigue and Insomnia among Patients on Hemodialysis. Kidney International Reports. 2019; 4(2): 285-292.

33. Wang SY, Zang XY, Liu JD, Cheng M, Shi YX, and Zhao Y. Indicators and Correlates of Psychological Disturbance in Chinese Patients Receiving Maintenance Hemodialysis: A Cross-Sectional Study. International Urology and Nephrology. 2015; 47(4): 679-689.

34. Wu CY, Han HM, Huang MC, Chen YM, Yu WP, and Weng LC. Effect of Qigong Training on Fatigue in Haemodialysis Patients: A Non-Randomized Controlled Trial. Complementary Therapies in Medicine. 2014; 22(2): 244-250.

35. Turk AC, Ozkurt S, Turgal E, and Sahin F. The Association Between the Prevalence of Restless Leg Syndrome, Fatigue, and Sleep Quality in Patients Undergoing Hemodialysis. Saudi Medical Journal. 2018; 39(8): 792-798.

36. Soliman HMM. Effect of Intradialytic Exercise on Fatigue, Electrolytes Level and Blood Pressure in Hemodialysis Patients: A Randomized Controlled Trial. Journal of Nursing Education and Practice. 2015; 5(11): 16-28.

37. Karakan S, Sezer S, and Ozdemir FN. Factors Related to Fatigue and Subgroups of Fatigue in Patients with End-Stage Renal Disease. Clinical Nephrology. 2011; 76(5): 358-364.

38. Davey CH, Webel AR, Sehgal AR, Voss JG, and Huml A. Fatigue in Individuals with End Stage Renal Disease. Nephrology Nursing Journal: Journal of the American Nephrology Nurses' Association. 2019; 46(5): 497-508.

39. Joshwa B and Campbell ML. Fatigue in Patients with Chronic Kidney Disease: Evidence and Measures. Nephrology Nursing Journal: Journal of the American Nephrology Nurses' Association. 2017; 44(4): 
337-343.

40. Bossola M, Di Stasio E, Antocicco M, Tazza L. Qualities of Fatigue in Patients on Chronic Hemodialysis. Hemodialysis International. 2013;
17(1):32-40.

41. Ting EYC, Yang AC, and Tsai SJ. Role of Interleukin-6 in Depressive Disorder. International Journal of Molecular Science. 2020; 21(6): 1-22. 